Journal of Thermal Engineering, Vol. 6, No. 4, pp. 633-650, July, 2020

Yildiz Technical University Press, Istanbul, Turkey

\title{
A TECHNO-ECONOMIC FEASIBILITY STUDY FOR REDUCING THE ENERGY CONSUMPTION IN A BUILDING: A SOLAR ENERGY CASE STUDY FOR BANDAR ABBAS
}

\author{
Shahin Bazarchi ${ }^{1}$, Gholam Reza Nabi Bidhendi², Iran Ghazi ${ }^{1}$, Alibakhsh Kasaeian ${ }^{3^{*}}$
}

\begin{abstract}
In this work, 13 different solutions for the optimization of energy consumption of a building located in the tropical city of Bandar Abbas are studied out via the EnergyPlus and TRNSYS (Transient System Simulation Tool) commercial codes. Then, the suggested solutions are economically studied and the most economically viable ones are proposed. Ultimately, an energy efficient consumption scheme is put forward with the approach of solar energy utilization. Results reveal that 9 out of 13 studied solutions are techno-economically viable; and by implementing these solutions the energy consumption of the building could be decreased by $81 \%$ up to $165624.1 \mathrm{kWh}$ as well as preventing $63022.66 \mathrm{~kg}$ of $\mathrm{CO}_{2}$ emission.
\end{abstract}

\section{Keywords: Building Energy Conservation, Techno-Economic Study, Solar Energy, EnergyPlus, TRNSYS}

\section{INTRODUCTION}

With the energy crisis turning into a global concern, solutions are sought for the energy issues. Increasing energy efficiency as well as renewable energies are seen as potential solutions out of this crisis, so many studies have been carried out to increase energy efficiency in energy sectors [1-8]. With regard to the household sector being a major energy consumer [1], one approach for lowering the total global energy consumption would be to optimize building energy demands and the application of green energies. Therefore, reducing the energy consumption of the building sector will significantly enhance the sustainable and environmental-friendly development, since the larger part of this energy is provided by fossil fuels, emitting greenhouse gases and accelerating the global warming. Various efforts are performed for predicting and modeling the building sector energy consumption. In a review, Zhao and Magoules [9] classified the building energy consumption prediction methods into 5 categories, namely engineering methods, statistical methods, neural networks, support vector machine, and Grey models. They reviewed the advantages and major drawbacks of each method. In another attempt, Balaras et al. [10] investigated the potentials of energy conservations in buildings. They followed the EPIQR methodology and software.

The methods of performing energy conservation are the subject of a vast number of scientific attempts for both the existing buildings and new building constructions. Chwieduk [11] investigated the modern and traditional options for building energy conservation. The traditional attempts include lowering energy needs, final energy demand, and the primary energy demand of the building, whereas modern options mostly include using renewable energies such as solar energy in active and passive modes. Since maintaining the comfort temperature in a building consumes a large part of the total building energy, insulation methods also play a crucial role in reducing the energy conservation of a building. Aditya et al. [12] reviewed the insulation materials for building energy conservation and compared the advantages and drawbacks of each. Recovering low-grade heat as well as heat storage via phase change materials (PCMs) are other useful approaches to energy conservation. Liu et al. [13] investigated the active low-grade energy recovery potential for this purpose. Khudhair and Farid [14], Tyagi and Buddhi [15], and Kenisarin and Kenisarin [16] reviewed the utilization of PCMs for heat storage, including solar energy, in building applications. Also, Sharifi et al. [17] investigated the application of PCMs in gypsum boards for energy conservation purposes. Dabiri et al. [18] investigated thermal analysis of a brick including PCM and ten air cavities using CFD in both the coldest and hottest days of Tehran in 2016. The result showed that in the summer, the latent heat storage constituted about $71 \%$ of the thermal storage. By contrast, in the winter, more than $72 \%$ of thermal storage was made up of sensible heat storage.

Also, the amplitude of the internal temperature variation in the summer and winter decreased by $48.5 \%$ and $44 \%$, respectively. Furthermore, cogeneration could also be utilized in buildings as investigated in [19]. Annad et al.

This paper was recommended for publication in revised form by Regional Editor Tolga Taner

${ }^{1}$ Disasters Management Department, Shakhes Pajouh Research Institute, Iran

${ }^{2}$ Faculty of Environment, University of Tehran, Tehran, Iran

${ }^{3}$ Faculty of New Sciences and Technologies, University of Tehran, Tehran, Iran

*E-mail address: akasa@ut.ac.ir, ghhendi@ut.ac.ir, shahin.bazarchi@gmail.com

Orcid id: 0000-0003-3037-6343, 0000-0003-3247-8773, 0000-0002-4340-190X

Manuscript Received 4 August 2018, Accepted 18 October 2018 
Journal of Thermal Engineering, Research Article, Vol. 6, No. 4, pp. 633-650, July, 2020

[20] was studied the influence of various operating parameters such as COP and flow rate using the concept of energy and exergy in a single-effect absorption system for building application. As a result, such system can easily be applied to the building systems for attaining thermal comfort and achieve passive cooling.

With the technology being developed and cost efficiency being justified, incorporating renewable energies in buildings for energy reduction is becoming vastly popular in the last decade. Among these energies, solar energy is the most popular one due to extensive availability and lower costs. Older attempts mostly includes passive systems [21] or solar water collectors, while newer ones are a combination of both methods in most cases [22]. Chan et al. [23] reviewed the passive solar heating and cooling technologies in buildings. One common passive method is to store solar energy within the walls using special mediums, as the cases presented in [24] and [25]. In another research [26] using innovative Trombe wall with extra glazing in the massive wall for capturing solar radiation in order to cover a part of the heating loads of a building located in Athens, Greece was investigated by means of the commercial software Solidworks Flow Simulation. The result showed that the new Trombe wall is the most appropriate technology, creating warmer indoor profile than the other cases, especially the hours between noon and afternoon. Mehrpooya et al [27] presents an optimal planning model of a hybrid renewable energy system to meet a real load with a combination of photovoltaic panels (PV), diesel generators and batteries using HOMER software. Su et al. [28] comparatively studied different patterns of solar energy utilization for different applications, including residential, official, commercial, and industrial districts. Photovoltaic (PV) systems are the most common patterns used for solar energy utilization in buildings due to ease of maintenance and application. Various attempts are performed in this area within the literature, two of them being presented in [29] and [30] to name a few. Another passive application in this field is utilizing specific windows along with dedicated control devices. In this way, both lighting, heating, and cooling requirements of the building could be enhanced leading to lower total energy consumption, as presented in [31] and [32]. Kuhn [33] also reviewed advanced control devices used in solar buildings. Finally, solar energy could also be utilized in buildings via heat pumps or collector heaters. This application mostly covers heating and cooling needs, although in case of organic Rankine cycles (ORC), power generation could also be considered. Various efforts are performed in this field. Modeling and analyses presented in [34] and [35] could be pointed out as examples.

While technical performance of solar building systems is the first issue to be investigated, the factor that makes them being practical is the price. Economical and feasibility assessments if accompanied by technical analysis, provide a comprehensive guide for integrating solar energy systems in buildings. Several attempts are performed in this field. Poppi et al. [36] presented a techno-economic review of solar heat pump systems utilized in buildings. Also, Quoilin et al. [37] reviewed the ORC systems in buildings from a techno-economic perspective. Jo et al. [38] presented a parametric techno-economic model for analyzing renewable energy integration in residential buildings. Also, Liu et al. [39] analyzed the general indicator for techno-economic assessment of renewable energies. Various attempts are performed in the field of techno-economic analysis of building PV systems. Buonomano et al. [40] present a detailed exergetic and techno-economic analysis of a building integrated photovoltaic thermal system, while Lang et al. [41] performed a techno-economic analysis on rooftop photovoltaic cells for self-consumption in residential and commercial buildings. Also, Liu et al. [42] conducted Techno-economic simulation and optimization of residential grid-connected PV system for the Queensland climate. Finally, Turkay and Telli [43] presented an economic analysis of standalone and grid-connected hybrid energy systems in buildings. According to the literature, there are variety of studies on energy conservation of building, but there are no studies to investigate different solutions including modern technology such as using renewable energy for a specific environment condition such hot and humid climate and present the applicable solutions for this condition. Since hot regions are more intense energy consumers, while they benefit from the higher solar insolation, in this study Bandar Abbas city with hot and humid climate condition is selected for the case study.

Hence, in this study different solutions for energy reduction are investigated for reducing energy consumption of a building in Bandar Abbas city where have a hot and humid climate. Iran is located inside the solar belt, and studies have revealed that solar appliances are suitable for application in the country and capable of supplying for a portion of the nation's energy demand. The city of Bandar Abbas consumes high energy, particularly during peak solar insolation. Therefore, energy efficiency and application of solar devices in the region can provide a significant reduction in city's energy consumption. 
Hereby, we first techno-economically analyze the energy efficiency solutions for energy efficiency in a nominal building in Bandar Abbas, Iran, including insulating and replacing the windows. Secondly, we study the optimum building equipping with solar energy systems. Ultimately, a suitable economical scheme is proposed which is capable of reducing the energy consumption of the nominal building. The present approach is an effective way to cut a considerable amount of household energy consumption in tropical regions, while being both environmentally benign and effective in curbing the foreseen energy crisis.

\section{THE BUILDING}

\section{Cooling and Heating Systems}

Due to the hot and humid climate of Bandar Abbas, its buildings requisite cooling, and there is no need for heating in cold seasons, due to the relatively high outdoor temperature. Electric water heaters and natural gas capsules are used for heating domestic water and cooking, respectively. Four split heat pump units, having compression cycles, cool the building, the capacity of which is $24222 \mathrm{Btu} / \mathrm{h}(7 \mathrm{~kW})$ for one unit and $15222 \mathrm{Btu} / \mathrm{h}(4.46 \mathrm{~kW})$ for the other three. One or two of them are usually active.

\section{Lighting Systems}

Energy saving light bulbs are used as follows: seven 58 watts and eight 42 watts bulbs inside the units, and twelve 22 watts bulbs for the corridors and the parking space.

\section{Building Energy Consumption}

The energy carriers used in this building are electricity and natural gas. The energy consumption of the building is shown with details in Table 1. The majority of the consumption is dedicated for cooling purposes.

Table 1. Energy consumption value of all the applications in the building

\begin{tabular}{|c|c|}
\hline Application & Consumption value (kWh) \\
\hline Cooling & 2172329.14 \\
\hline Heating & 2948 \\
\hline Domestic Hot Water & 1231 \\
\hline Lighting & 6289.53 \\
\hline Electric Devices and Appliances & 204438.36 \\
\hline Total Building Energy Consumption & \\
\hline
\end{tabular}

\section{SIMULATION OF THE BUILDING IN ENERGYPLUS}

In order to model the building in EnergyPlus software, a 3D design of the building structure is developed with Open Studio software at first, which incorporates a graphical user interface and depicted in Figure 1. 


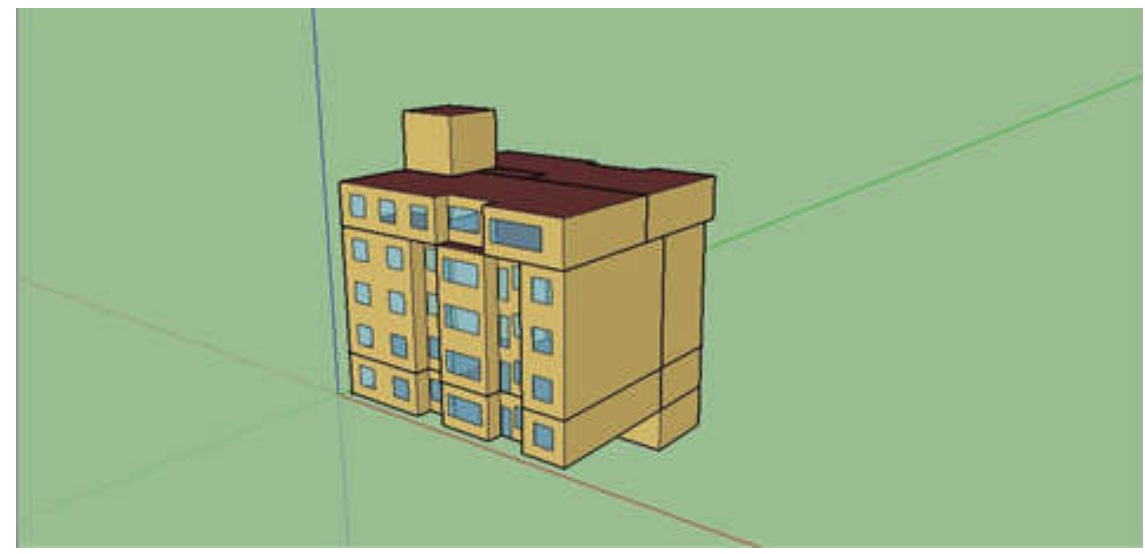

Figure 1. The building model in open studio

The first step in thermal modeling of a building in any energy simulator software is to define the thermal zones of the building. The Proper definition of the thermal zones both makes the results more reliable and decreases the required computational resource. Nine thermal zones were defined for the considered building. The probability of yielding considerable results is used for specifying the zones, e.g., the difference between the top and middle floors, between north and south zones, and between the underground and over-the-ground spaces were recognized to be significant. The thermal zones are considered as follows:

-Parking

-Stairs

-The northern part of the first-floor unit

-The southern part of the first-floor unit

-The northern part of the $2^{\text {nd }}$ to $4^{\text {th }}$-floor units

-The corridor between the units

-The northern part of the $5^{\text {th }}$-floor unit

-The southern part of the $5^{\text {th }}$-floor unit

The thermal zones are illustrated in Figure 2 modeled in an Open Studio environment and specified with different colors.

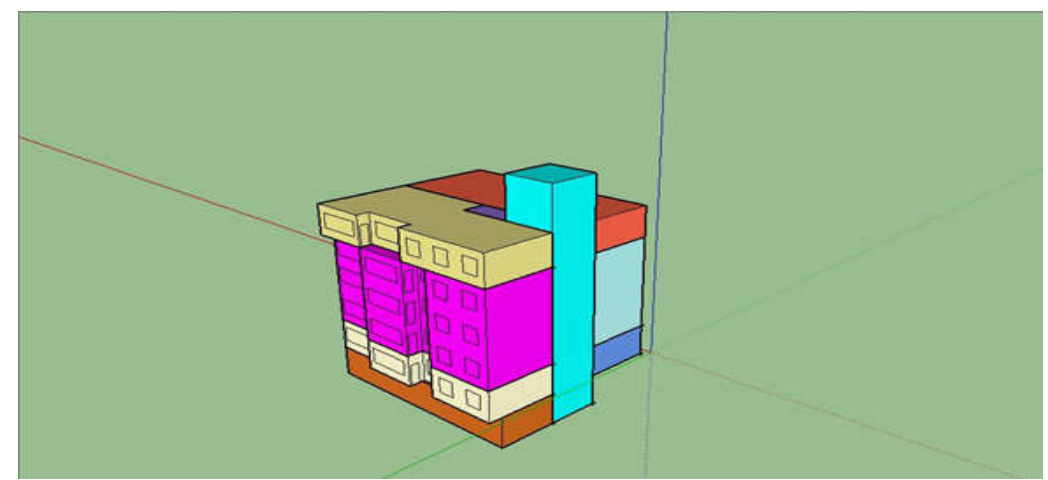

Figure 2. Thermal zones presented with specific colors in open studio modeling environment

The model is then transferred to EnergyPlus software environment, adding other required data including structural layers information, wall properties, installations, lighting systems, and residents' schedule. Moreover, the weather data are extracted from the file reported by the Mehrabad, Tehran, weather station available on EnregyPlus website. 


\section{VALIDATION}

The best criterion for establishing a comparison between the thermal performance of the modeled and the real studied building is energy consumption. The energy consumption data of the buildings were analyzed as a first step toward establishing the comparison. Electricity can be regarded as the main energy source (fuel) of the building since cooling is conducted with compression refrigeration and the domestic hot water is provided with the electric water heater.

Table 2. Actual and simulated power consumption of the building

\begin{tabular}{|c|c|c|}
\hline Date Range & Simulation $(\mathrm{kWh})$ & Electricity Bill (kWh) \\
\hline $21 \mathrm{Mar}-20 \mathrm{Apr}$ & 14834.75 & 14175 \\
\hline $21 \mathrm{Apr}-21 \mathrm{May}$ & 21193.77 & 19694.92 \\
\hline 22 May - 21 Jun & 28215.60 & 25474.96 \\
\hline 22 Jun - 22 Jul & 28087.09 & 26094.25 \\
\hline $23 \mathrm{Jul}-22$ Aug & 27119.71 & 26183.43 \\
\hline 23 Aug-22 Sep & 28936.45 & 26200.58 \\
\hline $23 \mathrm{Sep}-22$ Oct & 20078.65 & 18110.4 \\
\hline 23 Oct $-21 \mathrm{Nov}$ & 14160.98 & 16661.4 \\
\hline $22 \mathrm{Nov}-21 \mathrm{Dec}$ & 6985.43 & 7585.62 \\
\hline 22 Dec-20 Jan & 6000.69 & 6577.2 \\
\hline $21 \mathrm{Jan}-19 \mathrm{Feb}$ & 6019.66 & 8838.2 \\
\hline $20 \mathrm{Feb}-20 \mathrm{Mar}$ & 7775.13 & 8842.4 \\
\hline
\end{tabular}

By studying Table 2 and Figure 3, which depict the simulated power consumption of the building, it is observed that the overall discrepancy between the actual and the simulated energy consumption values is $10 \%$, which is due to the fact that the comfort range is defined to be $23-27^{\circ} \mathrm{C}$ for software; while the HVAC is assumed to be ON continuously throughout the year. However, the occupants may be out for days, or the room temperature may rise over $27^{\circ} \mathrm{C}$ in spite of the presence of the occupants. Therefore, the simulation carried out with EnergyPlus software is considered as an acceptable model of the actual building, and can be used for the forthcoming study of the effectiveness of energy efficiency measures.

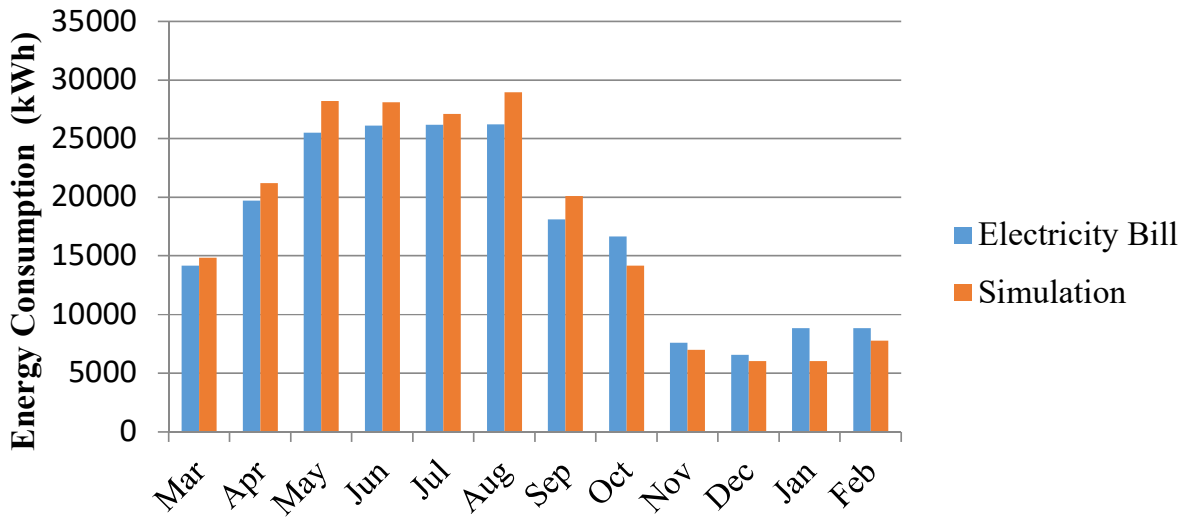

Figure 3. Real and simulated power consumption of the building 


\section{ERROR ANALYSIS}

For the purpose of conducting a detailed error analysis, the statistical methods consisting the normalized mean absolute error (MAEnorm), and the mean relative error (MRE) methodologies are used for this validation by means of following formula.

$$
\begin{gathered}
M A E_{\text {norm }}=\frac{1}{y * \operatorname{avg}\left(m_{i}\right)} \sum\left|e_{i}-m_{i}\right| \\
M R E=\frac{1}{y} \sum\left|\frac{e_{i}-m_{i}}{m_{i}}\right|
\end{gathered}
$$

where e and $\mathrm{m}$ are the theoretical and experimental values, respectively. Also, $\mathrm{y}$ is the number of value for comparison. Based on the calculation, the percent value of the MAE norm and MRE are obtained as $9.8 \%$ and $10.9 \%$ respectively.

\section{TECHNICAL ANALYSIS OF ENERGY EFFICIENCY SOLUTIONS FOR THE BUILDING}

In this section, the simulation is used for analyzing the effectiveness of energy efficiency measures taken in the studied building. In the following, 13 energy conservation solutions are investigated and the value of energy and $\mathrm{CO}_{2}$ saving is presented.

Thermal insulation of the ceiling:

One of the cost-effective ways for energy saving is insulation which act as a barrier to heat loss. Based on the studies using of glass wool in tropical condition was recommended as insulation [44]; so, $10 \mathrm{~cm}$ thick glass wool is applied in the current study. The effect of insulating the ceiling with $10 \mathrm{~cm}$ thick glass wool is shown in Table 3 . As Table 3 suggests, insulating the ceiling cut $10 \%$ of cooling power consumption of the building, equal to $17232.91 \mathrm{kWh}$. Also, $72 \%$, equal to $15581 \mathrm{kWh}$ of heating power consumption was saved. Thus, an overall $32814.21 \mathrm{kWh}$ is saved annually, which prevents $11154.711 \mathrm{~kg}$ of $\mathrm{CO}_{2}$ emission.

Table 3. Energy consumption with and without ceiling insulation

\begin{tabular}{|c|c|}
\hline Energy required for cooling with insulated ceiling $(\mathrm{kWh})$ & 155096.23 \\
\hline Energy required for heating with insulated ceiling $(\mathrm{kWh})$ & 6059.39 \\
\hline Energy required for cooling in current condition $(\mathrm{kWh})$ & 172329.14 \\
\hline Energy required for heating in current condition $(\mathrm{kWh})$ & 21640.69 \\
\hline
\end{tabular}

\section{Thermal Insulation of the Walls}

Considering the humid climate of Bandar Abbas, two layers of breathable waterproof membranes inside and outside should be considered in addition to the regular $5 \mathrm{~cm}$ thermal insulator layer. The effect of thermally insulating the walls with polystyrene is investigated here. As is evident in Table 4 , an $8 \%$ reduction, equal to $13786.33 \mathrm{kWh}$, was observed in cooling energy demand, and $76 \%, 16446.92 \mathrm{kWh}$, the reduction was observed in heating energy demand. A total power saving of $30233.26 \mathrm{kWh}$ is reachable for the building with thermal insulation of the walls, which prevents the emission of $9976 \mathrm{~kg}$ of $\mathrm{CO}_{2}$.

Table 4. Energy consumption with and without wall insulation

\begin{tabular}{|c|c|}
\hline Cooling energy consumption with wall insulation $(\mathrm{kWh})$ & 158544.8 \\
\hline Heating energy consumption with wall insulation $(\mathrm{kWh})$ & 5193.766 \\
\hline Cooling energy consumption without wall insulation $(\mathrm{kWh})$ & 172329.14 \\
\hline Heating energy consumption without wall insulation $(\mathrm{kWh})$ & 21640.69 \\
\hline
\end{tabular}




\section{Utilizing Low-Emissivity Films}

In order to study the effect of UV light blocking on energy consumption, low-emissivity windows are used instead of the current regular windows of the building. This is also achievable with laminating the regular windows with a low-emissivity film. Since the cooling load reduction is a significant goal, the low-emissivity layer is added to the inner surface of the outer glaze of a double-glazed window. The EnergyPlus results revealed that the low-emissivity film is capable of impeding sunlight UV and cutting $1723.292 \mathrm{kWh}$ equal to $1 \%$ of the energy required for cooling, as presented in Table 6. However, reducing the energy gain from sunlight causes the heating load to increase by 865.62 $\mathrm{kWh}(4 \%)$. Overall, using low-emissivity windows saves $857.66 \mathrm{kWh}$ annually and prevents $283 \mathrm{~kg}$ of $\mathrm{CO}_{2}$ emission.

Table 5. Specifications of the low-emissivity window (laminated film on the outer glaze)

\begin{tabular}{|l|l|}
\hline Thickness $(\mathrm{m})$ & 0.005 \\
\hline Solar beam transmittance in perpendicular & 0.65 \\
\hline Solar beam reflectance in perpendicular, outer surface & 0.22 \\
\hline Solar beam reflectance in perpendicular, inner surface & 0.17 \\
\hline Visible light transmittance in perpendicular & 0.84 \\
\hline Visible light reflectance in perpendicular, outer surface & 0.078 \\
\hline Visible light reflectance in perpendicular, inner surface & 0.055 \\
\hline Infrared spectral hemispherical emissivity, outer surface & 0.1 \\
\hline Infrared spectral hemispherical emissivity, inner surface & 0.84 \\
\hline Conductivity $(\mathrm{W} /(\mathrm{m} . \mathrm{K}))$ & 1.05 \\
\hline
\end{tabular}

Table 6. Comparison of cooling and heating energy demand with and without laminating the windows with low-emissivity film

\begin{tabular}{|l|l|}
\hline Cooling energy demand with laminated low-e film $(\mathrm{kWh})$ & 170605.8 \\
\hline Heating energy demand with laminated low-e film $(\mathrm{kWh})$ & 22506.32 \\
\hline Current cooling energy demand & 172329.14 \\
\hline Current heating energy demand & 21640.69 \\
\hline
\end{tabular}

\section{Installing Horizontal Shades for Windows}

Considering the fact that the major energy consumption share of the considered building is dedicated to cooling, our priority was to decrease the cooling load. Thus, installing shades for windows is desirable in a way that effectively prevents direct sunlight of the hot seasons from entering the inner space, while significantly preserving the direct gain of sunlight in cold seasons. Regarding the altitude of the sun, southward windows provide the chance of utilizing horizontal shades in order to fulfill the aforementioned goal. The acquired results revealed that installation of horizontal shades over southward windows decreased the building cooling load by $46528.87 \mathrm{kWh}(27 \%)$, while the heating load of the cold days is also increased by 5974.118 (95\%) which is due to the decreased direct solar heat gain, as shown in Table 7. The cooling load reduction is higher than the heating load increase, which indicates that installing horizontal shades for the windows would be useful, being capable of saving $40554.75 \mathrm{kWh}$ of the building's power consumption as well as preventing $13383.07 \mathrm{~kg}$ of $\mathrm{CO}_{2}$ emitting to the atmosphere.

Table 7. Energy demand with and without the horizontal shades

\begin{tabular}{|c|c|}
\hline Cooling load after installing shades $(\mathrm{kWh})$ & 125800.2722 \\
\hline Heating load after installing shades $(\mathrm{kWh})$ & 12262.66275 \\
\hline Current cooling load $(\mathrm{kWh})$ & 172329.14 \\
\hline Current heating load $(\mathrm{kWh})$ & 6288.545 \\
\hline
\end{tabular}




\section{Replacing the Lights with LED Light Bulbs as Well as Lowering the Number of Light Bulbs}

20 and 10 Watt LED light bulbs are recommended for replacing the existing 85 and 40 Watt compact fluorescent energy saving light bulbs (CFL) of the building, respectively. Numerous 80 and 40 watt light bulbs are currently used in the considered building for several hours a day, the replacement of which with LED light bulbs would significantly decrease building's power demand. As is evident in Table 8, using LED light bulbs annually decreases the overall electricity consumption by $76 \%$ equal to $939.8 \mathrm{kWh}$ and prevents $319 \mathrm{~kg}$ of $\mathrm{CO}_{2}$ emission. This economically justifies the use of relatively uncostly LED light bulbs, specifically in the halls.

Table 8. Lighting power demand of the building before and after LED light bulbs replacement

\begin{tabular}{|c|c|}
\hline Annual power consumption of LED light bulbs (kWh) & 292 \\
\hline Current (CFL) annual power consumption kWh & 1231.88 \\
\hline
\end{tabular}

\section{Using Green Walls}

Growing adequate greenery over the building's facades is one of the most affordable, economically viable methods of environmental control and energy saving. The method works with preventing the undesirable effects of intense direct sunlight over the structure in summer. The temperature of the green surface is 11 to $25^{\circ} \mathrm{C}$ lower than that of the similar surface without the plants' shades. Also, the air temperature is 1 to $5^{\circ} \mathrm{C}$ lower in the presence of greenery, according to US Environmental Protection Agency (EPA). The southern and northern facades of the building, which inhere the capability of growing plants on, are stone walls with a thermal resistance of $0.52 \mathrm{~W} / \mathrm{m}^{2} \mathrm{~K}$. With the plantation on the walls, thermal resistance needs to be recalculated. According to the empirical studies on the thermal resistance of still air layer adjacent to the wall [45], the overall thermal resistance of a green façade is 0.64 .

As seen from the simulation results, listed in Table 9, it is evident that by covering the building envelope via greenery, the cooling and heating loads could be decreased by $3 \%$ equal to $5169.874 \mathrm{kWh}$ and $19 \%$ equal to 4111.731 $\mathrm{kWh}$, respectively; which sum up to $9281.605 \mathrm{kWh}$ and prevent $3062.92 \mathrm{~kg}$ of $\mathrm{CO}_{2}$ emission.

Table 9. Cooling and heating loads, before and after using green walls

\begin{tabular}{|c|c|}
\hline Current cooling load $(\mathrm{kWh})$ & 172329.14 \\
\hline Current heating load $(\mathrm{kWh})$ & 21640.69 \\
\hline Cooling load with the green wall $(\mathrm{kWh})$ & 167159.2658 \\
\hline Heating load with the green wall $(\mathrm{kWh})$ & 17528.9589 \\
\hline
\end{tabular}

\section{Controlling HVAC Using BMS}

In order to investigate the energy saving effectiveness of this solution, the presence and absence times of the residents of one unit was studied, and it was found that the residents are usually out for 2 hours a day, and leave the heat pump split unit of $18000 \mathrm{Btu} / \mathrm{h}$ working. Therefore, excluding the three cold months, during nine mild and hot months, the heat pump is working to cool the space while the residents are out. Building management system (BMS) allows the residents to switch the cooler about half an hour before returning home, or to remote control the cooler when they are away for days. Assuming the residents are away for five days a year (120 hours) and they are absent for 2 hours daily, this system saves $12 \%(20679.49 \mathrm{kWh})$ on the electricity bill, which also prevents the annual release of $6824 \mathrm{~kg}$ of $\mathrm{CO}_{2}$.

Table 10. Power demand before and after BMS installation

\begin{tabular}{|c|c|}
\hline Current power demand for cooling $(\mathrm{kWh})$ & 172329.14 \\
\hline Power demand for cooling with BMS $(\mathrm{kWh})$ & 151649.64 \\
\hline
\end{tabular}




\section{Greenhouse for Heating}

In order to investigate the effect of building a greenhouse on the room condition, a greenhouse was added to the model of the building, where there is currently a balcony (attached to the room). The greenhouse walls receive sunlight only from one direction, due to the plan of the balcony. The balcony has a width of $1.5 \mathrm{~m}$ and a length of $3.5 \mathrm{~m}$. Cooling and heating loads are recalculated with the greenhouse in place, and the results are plotted in Figure 4 and Figure 5, for before and after of incorporating the greenhouse, respectively.

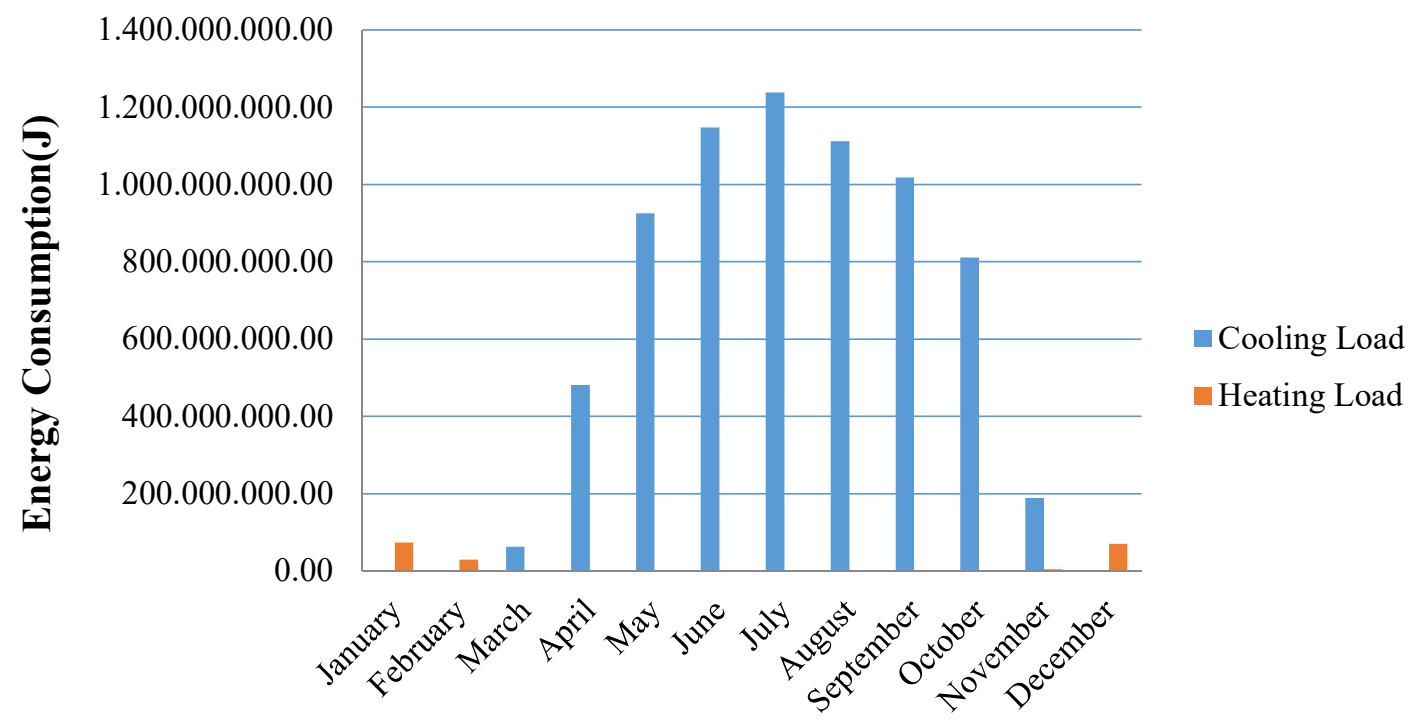

Figure 4. The current cooling and heating loads of the room

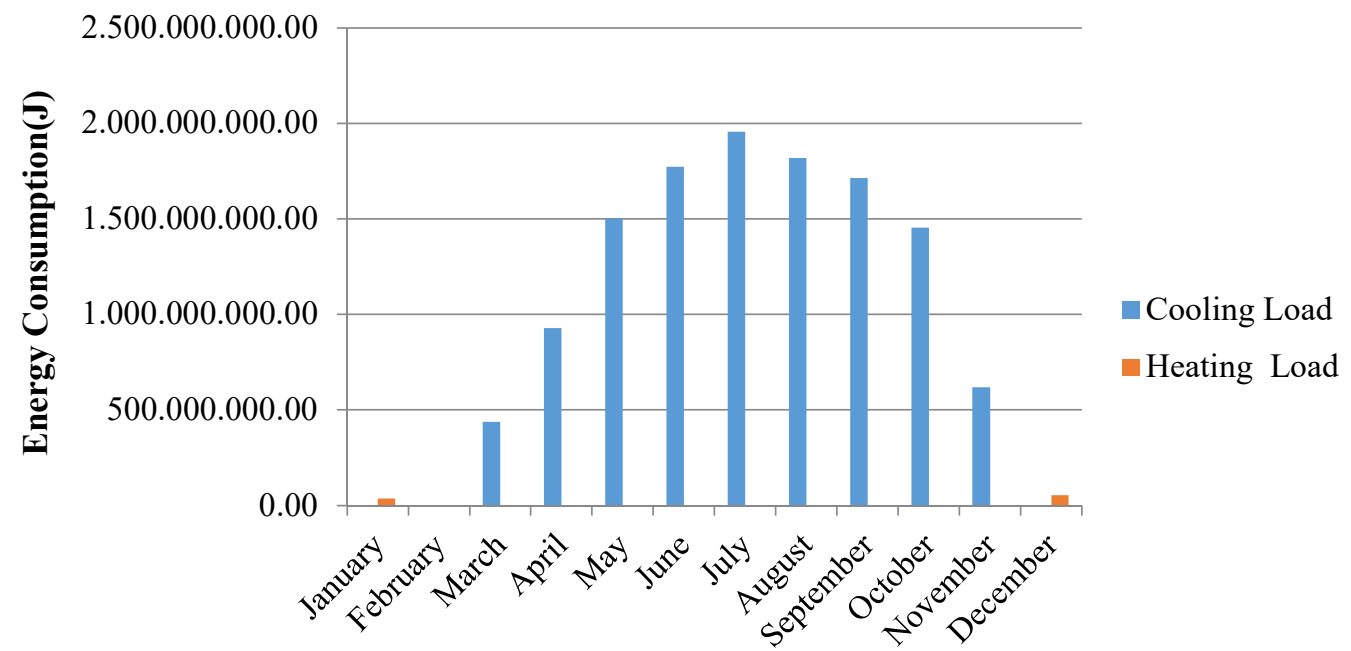

Figure 5. Cooling and heating loads of the room with a greenhouse instead of the balcony

As is evident from Table 11, the greenhouse increases the cooling load of the room by $1448.379 \mathrm{kWh}$, while decreasing the heating load by $24 \mathrm{kWh}$. Therefore, considering the massive increase in the cooling load of the hot months, which is incomparable with the decrease in the heating load of the cold months, it is concluded that this type of measure is not suitable for this climate. 
Table 11. Energy consumption for the room with and without the greenhouse

\begin{tabular}{|c|c|}
\hline Cooling load of the room $(\mathrm{kWh})$ & 1939.640 \\
\hline Heating load of the room $(\mathrm{kWh})$ & 48.917 \\
\hline Cooling load of the room with a greenhouse $(\mathrm{kWh})$ & 3388.020 \\
\hline Heating load of the room with a greenhouse $(\mathrm{kWh})$ & 24.310 \\
\hline
\end{tabular}

\section{Integrating Solar Heat Reservoir in the Building Envelope}

In climates with major hot or cold days, e.g., tropical and polar climates, utilizing heat mass effect in building envelope might even inflict adverse results. This way, both interior and exterior walls tend to reach the mean daily temperature, which is for sure too warm or too cold and out of the comfort range. Therefore, in a hot and humid climate like that of Bandar Abbas, which demands open building plans to use breezes, masonry with low heat capacity are preferred, and application of heat reservoirs inside the walls is refuted.

\section{Installing Photovoltaic Systems on the Roof}

PV SOL commercial software was used in order to investigate the application of a photovoltaic (PV) system on the roof with the aim of supplying the electricity demand of the building. The performed model is depicted in Figure 6. The modules were installed with $37^{\circ}$ inclination since Bandar Abbas is located on $27^{\circ} \mathrm{N}$ of latitude.

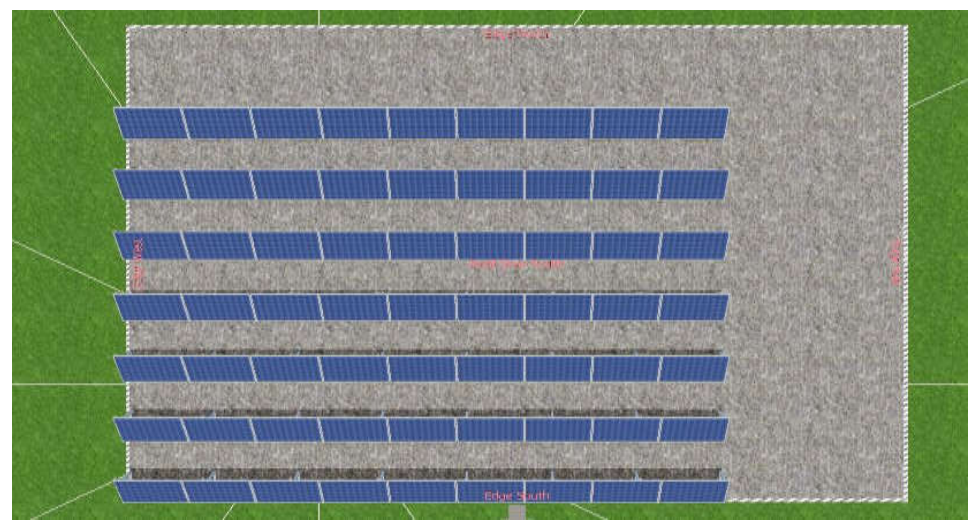

Figure 6. PV module arrangement modeled in PV SOL

The $\mathrm{DC}$ voltage $\left(\mathrm{V}_{\mathrm{dc}}\right)$ was chosen to be $48 \mathrm{~V}$. In order to find the number of series modules, $\mathrm{V}_{\mathrm{dc}}$ should be divided by a single module voltage, being $12 \mathrm{~V}$ in the present study.

$$
N_{s}=\frac{V_{d c}}{V_{m}}=\frac{48}{12}=4
$$

In order to find how many strings should be set up parallel to each other, the peak power demand of the building is divided by the power each string can generate as follows:

$$
N_{s}=\frac{P_{\text {peak }}}{P_{m} \times N_{s}}=\frac{4.48 \times 1000}{4 \times 80}=14
$$

With 14 parallel strings, the total number of modules would be 56 modules and the whole area is acquired to be $91.3 \mathrm{~m}^{2}$, assuming $0.4 \mathrm{~m}^{2}$ of each module area. 
Monthly production of the designed PV system is shown in Table 12 as well as Figure 7. Based on Figure 7, the highest and lowest production are about 2000 and $1600 \mathrm{kWh}$ in May and December, respectively. The power generation output is $13.5 \mathrm{~kW}$ and produces $21876 \mathrm{kWh}$ of electricity per year. This case is accounted for $10 \%$ of the annual electricity demand of the building, i.e., $209407.9 \mathrm{kWh}$ and prevents $13113 \mathrm{~kg}$ of $\mathrm{CO}_{2}$ emission.

Table 12. PV SOL simulation results

\begin{tabular}{|c|c|}
\hline Climate data & Bandar Abbas (1986-2005) \\
\hline PV Generator Output & $13.5 \mathrm{kWp}$ \\
\hline PV Generator Surface & $91.3 \mathrm{~m}^{2}$ \\
\hline Number of PV modules & 56 \\
\hline Number of inverters & 1 \\
\hline
\end{tabular}

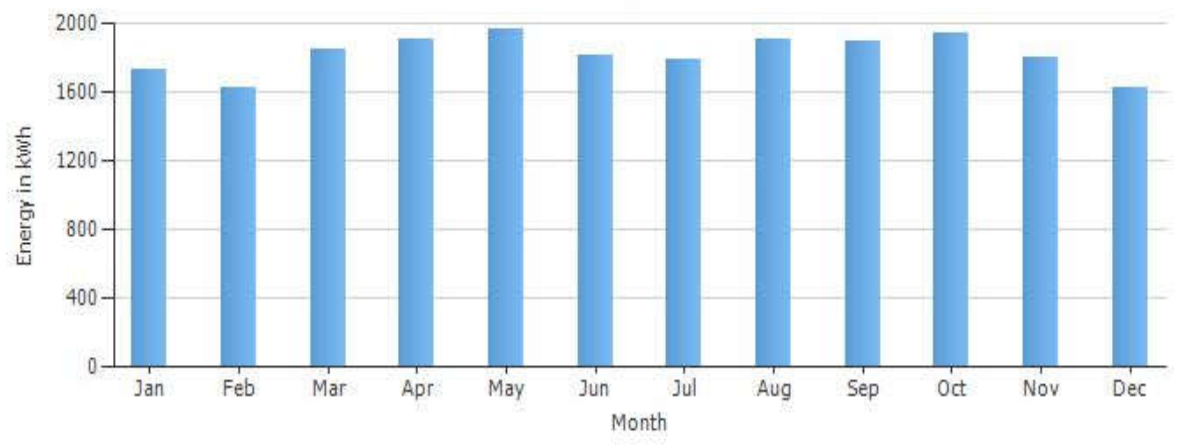

- PV Generator Energy (AC grid)

Figure 7. Monthly power generation of the PV system

\section{Installing PV Cells Over the Southern Window Shades}

We can further harvest the solar energy potential of the southern façade, in order to compensate for the high electric energy consumption of the building, each unit of which has two heat pump split units activated for several hours a day. It is possible to install PV panels on window shades of the southern façade, which was previously suggested, in order to resource a portion of the heat pumps energy demand. With each window having one module, 20 PV modules assumed over the shades of southern windows were able to produce a considerable amount of electricity, as shown in Figure 8. It is found out from Figure 8 that installing PV panels on the shading of southern windows leads to $6479 \mathrm{kWh}$ electricity production, i.e., preventing $3888 \mathrm{~kg} \mathrm{CO}_{2}$ emission. Also, the highest and lowest electricity production are for May and December, respectively.

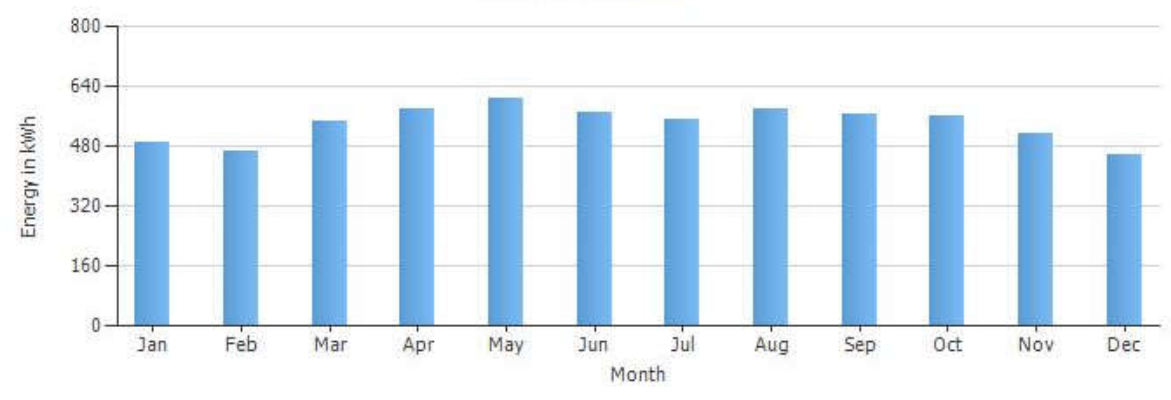

EV PV Generator Energy ( $A C$ grid)

Figure 8. The monthly energy generation of PV modules over the window shades 


\section{Utilizing Solar Heating System}

TSOL commercial software was used in order to simulate the application of solar water heater. Flat plate solar collectors (FPC) have proven to be more economically viable in tropical regions than evacuated tube solar collectors (ETC) [46]. Therefore, in this simulation, 3 Solar Polar FPCs are used, each having $1.5 \mathrm{~m}^{2}$ of absorber area with 0.96 absorption coefficient. Each unit is assumed to house a household of 5 members. Figure 9 shows a schematic of the solar water heater designed in TSOL. In order to find the optimum inclination of the collectors, the energy generated by the collectors is studied over the year and depicted in Figure 10 . The results show that an inclination of $37^{\circ}$ provides the highest annual useful energy gain. The efficiency of the solar collector is investigated by the following formula:

$$
\eta=\eta_{o}+a_{1} \frac{\left(T_{i n}-T_{a}\right)}{G}-a_{2} \frac{\left(T_{i n}-T_{a}\right)^{2}}{G}
$$

where $\eta$ is the collector efficiency, and $\eta_{o}, a_{1}$ and $a_{2}$ are constant coefficients which can be evaluated analytically or experimentally. These are presented by the solar collector manufacturer as the standard performance data. Also, $\mathrm{G}$ is the solar irradiance, $T_{i n}$ and $T_{a}$ are the collector inlet temperature and ambient temperature, respectively

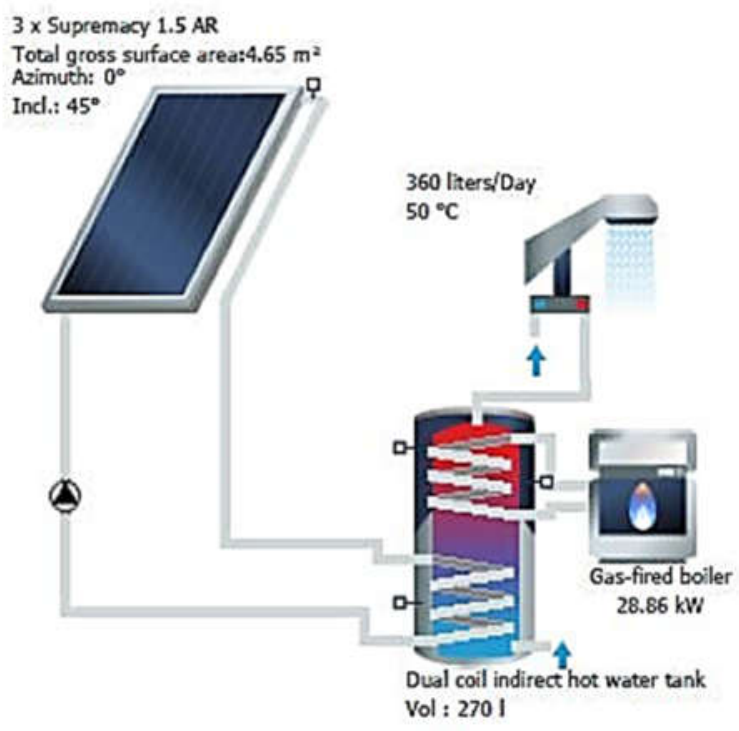

Figure 9. Schematic of the solar water heater designed in TSOL

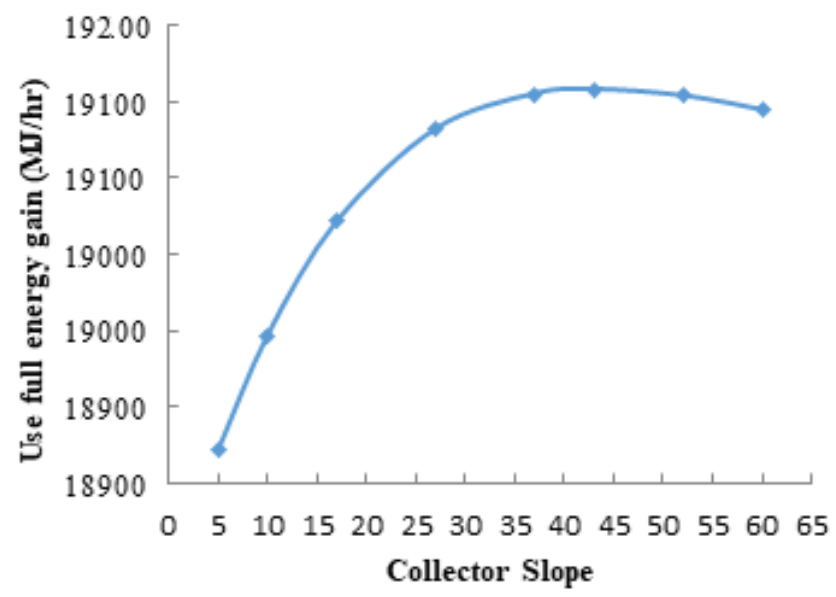

Figure 10. Collector useful energy gain for various collector inclination angles 
According to the results of the annual simulation, shown in Figure 11, by means of $4.65 \mathrm{~m}^{2}$ solar collector, $2766 \mathrm{kWh}$ annual energy consumption is saved, and of $1018.96 \mathrm{~kg} \mathrm{CO}_{2}$ emission is prevented. Based on this figure, the solar fraction is $70 \%$, and the system efficiency is $34.4 \%$.

\section{Results of annual simulation}

\begin{tabular}{|c|c|c|}
\hline \multicolumn{2}{|l|}{ Installed collector power: } & $3.26 \mathrm{~kW}$ \\
\hline \multicolumn{2}{|l|}{ Installed solar surface area (gross): } & $4.65 \mathrm{~m}^{2}$ \\
\hline Irradiation on to collector surface (active): & $8.05 \mathrm{MWh}$ & $1,943.75 \mathrm{kWh} / \mathrm{m}^{2}$ \\
\hline Energy delivered by collectors: & $4.10 \mathrm{MWh}$ & $991.11 \mathrm{kWh} / \mathrm{m}^{2}$ \\
\hline Energy delivered by collector loop: & $3,003.07 \mathrm{kWh}$ & $725.38 \mathrm{kWh} / \mathrm{m}^{2}$ \\
\hline DHW heating energy supply: & & $3.49 \mathrm{MWh}$ \\
\hline Solar contribution to DHW: & & $2,766.73 \mathrm{kWh}$ \\
\hline Energy from auxiliary heating: & & $1,183.9 \mathrm{kWh}$ \\
\hline Natural gas $(H)$ savings: & & $481.9 \mathrm{~m}^{3}$ \\
\hline CO2 emissions avoided: & & $1,018.96 \mathrm{~kg}$ \\
\hline DHW solar fraction: & & $70.0 \%$ \\
\hline Fractional energy savings (DIN CEN/T & & $71.7 \%$ \\
\hline System efficiency: & & $34.4 \%$ \\
\hline
\end{tabular}

Figure 11. Results of annual simulation of the solar water heater

\section{Solar Absorption Cooling System}

Major components of an absorption cooling system include absorption chiller, boiler, and cooling tower. In solar absorption cooling systems, solar collectors replace the boiler and generate the required heat of the system. Cooling towers cool the condenser hot water cycle. The cooling process in cooling towers is based on surface evaporation of a portion of the water subject to the air stream. Therefore, the towers are built with extended evaporation surfaces to provide water with more surface in contact with air, which makes cooling towers vast in dimensions. Cooling towers, just as other evaporative devices, perform effectively in hot-arid and hot-semi-arid regions, while are of virtually no use in the humid areas. The monthly and annual average relative humidity of Bandar Abbas from 2010 to 2016 are listed in Table 13.

Table 13. Bandar Abbas's relative humidity over six consecutive years

\begin{tabular}{|c|c|c|c|c|c|c|c|c|c|c|c|c|c|}
\hline Year & Jan & Feb & Mar & Apr & May & Jun & Jul & Aug & Sep & Oct & Nov & Dec & Average \\
\hline 2010 & 63 & 67 & 70 & 63 & 66 & 67 & 76 & 79 & 62 & 63 & 72 & 60 & 67 \\
\hline 2011 & 67 & 66 & 71 & 68 & 59 & 63 & 73 & 74 & 68 & 66 & 61 & 78 & 68 \\
\hline 2012 & 73 & 77 & 80 & 67 & 62 & 65 & 59 & 75 & 77 & 67 & 49 & 62 & 68 \\
\hline 2013 & 71 & 67 & 75 & 72 & 61 & 67 & 70 & 74 & 72 & 72 & 67 & 69 & 70 \\
\hline 2014 & 74 & 70 & 70 & 63 & 56 & 56 & 71 & 66 & 66 & 64 & 63 & 65 & 65 \\
\hline 2015 & 63 & 73 & 63 & 57 & 55 & 63 & 66 & 70 & 72 & 66 & 68 & 48 & 64 \\
\hline 2016 & 65 & 66 & 65 & 59 & 67 & 63 & 63 & 65 & 71 & 62 & 54 & 67 & 64 \\
\hline
\end{tabular}

As is evident from Table 13, during the six consecutive years, the average relative humidity had always been over $60 \%$, which implies the unsuitability of solar absorption cooling system for this city, which requires evaporative cooling towers. 


\section{ECONOMIC STUDY OF THE PROPOSED SOLUTIONS}

13 solutions were proposed and technically studied in the previous section with the aim of energy efficiency in the nominal building in Bandar Abbas as a hot and humid region. In this section, these solutions will be studied from economic aspects, and the propositions will get more practical regarding the energy efficiency of the buildings in the hot and humid city of Bandar Abbas. The payback time for each solution is estimated to prioritize and categorize the solutions. For calculating the cost savings provided by each solution, the energy saving (in $\mathrm{kWh}$ ) of each one is multiplied by the price rate per $\mathrm{kWh}(0.0238 \$)$. The payback time is derived from the following equation. Table 14 lists the costs and payback periods of all solutions.

$$
\text { Payback time }=\frac{\text { Innitial investment }}{\text { net annual saving }}
$$

Table 14. Economic estimation of the solutions.

\begin{tabular}{|c|c|c|c|c|c|}
\hline Solutions & $\begin{array}{c}\text { Energy } \\
\text { Saving/Generation } \\
(\mathrm{kWh})\end{array}$ & $\begin{array}{c}\mathrm{CO} 2 \\
\text { Emission } \\
\text { Reduction } \\
(\mathrm{kg})\end{array}$ & $\begin{array}{l}\text { Capital costs } \\
\quad \text { (US\$) }\end{array}$ & $\begin{array}{c}\text { Net annual } \\
\text { cost savings } \\
\text { (US\$) }\end{array}$ & $\begin{array}{l}\text { Payback time } \\
\quad(\mathrm{yr})\end{array}$ \\
\hline $\begin{array}{l}\text { Roof thermal } \\
\text { insulation }\end{array}$ & 32814.21 & 11154.71 & 65714.28571 & 7812.907143 & 8.4 \\
\hline $\begin{array}{l}\text { Walls thermal } \\
\text { insulation }\end{array}$ & 30233.26 & 9976 & 8671.371429 & 7198.395238 & 1.2 \\
\hline $\begin{array}{l}\text { Low-emissivity } \\
\text { film for the } \\
\text { windows }\end{array}$ & 857.66 & 283 & 15750 & 204.2047619 & 77.12 \\
\hline $\begin{array}{l}\text { Shading for } \\
\text { windows }\end{array}$ & 40554.75 & 13383.07 & 45000 & 9655.892857 & 4.66 \\
\hline LED light bulbs & 939.8 & 319 & 6083.333333 & 223.7619048 & 27.18 \\
\hline BMS & 20679.49 & 6824 & 33333.33333 & 4923.688095 & 6.76 \\
\hline Green walls & 9281.61 & 3062.92 & 4761.904762 & 2209.905952 & 2.15 \\
\hline Rooftop PV & 21876 & 13113 & 48214.28571 & 5208.571429 & 9 \\
\hline PV on facade & 6479 & 1018.96 & 14285.71429 & 1542.619048 & 9 \\
\hline Solar collector & 2766 & 3888 & 14047.61905 & 658.5714286 & 21 \\
\hline $\begin{array}{l}\text { Solar absorption } \\
\text { cooling }\end{array}$ & \multicolumn{5}{|c|}{$\begin{array}{l}\text { Considering the humid climate of Bandar Abbas, the evaporative cooling tower will not } \\
\text { perform effectively. Hence, an absorption cooling system is not suitable for the region. }\end{array}$} \\
\hline Greenhouse & \multicolumn{5}{|c|}{$\begin{array}{l}\text { The greenhouse slightly reduces the heating load, while causing significant cooling load } \\
\text { during nine warm months. Therefore, the solution is not suggested. }\end{array}$} \\
\hline $\begin{array}{c}\text { Solar heat } \\
\text { reservoir }\end{array}$ & \multicolumn{5}{|c|}{ Bandar Abbas's climate is continuously warm, making the solution unsuitable for the region. } \\
\hline
\end{tabular}


Investigating Table 14, the priorities of the solutions are as follows:

- The highest cut in the electricity demand of the building is incurred by installing shades over the southern windows, with a payback time of 4.66. This measure not only suggests short payback time, but it also brings comfort to the residents as well.

- $\quad$ The second energy saver solution is the implementation of insulation for the walls and roof, with 1.2 and 8.4 years of payback times, respectively. This solution brings comfort to the residents and prevents the humidity infiltration.

- The next appropriate measure is BMS utilization with 6.76 years of payback time. This will save energy along with bringing comfort and ease of mind to the residents since the interior temperature is set to the desired level when the residents return after a while.

- The next proposed solution is building green walls over the façade of the building, which has both aesthetic and cooling/heating energy saving aspects with a payback time of 2.15 years.

- The other solution which significantly shrinks the electricity bills of the building is replacing the lights with LED light bulbs. If applied to all the units of the building, the payback time will be 27 years, which is an ideal length of time, regarding its energy saving and capital cost.

- Utilizing PV systems, rooftop and wall mounted, is suggested as well as using a solar water heater, although with considering their environmental aspects. The payback time for these solutions is 9 and 21 years, respectively.

- Laminating the glazes of the southern windows with the low-emissivity film will cause an $857.66 \mathrm{kWh}$ reduction in energy consumption, having a payback time of 77 years. This solution is not suggested.

Therefore, 9 out of 13 studied solutions are techno-economically viable, and their implementation can reduce the building energy consumption by $81 \%$ to $38814.25 \mathrm{kWh}$ as well as preventing $63022.66 \mathrm{~kg}$ of $\mathrm{CO}_{2}$ emission. Table 15 lists the building energy consumption before and after implementing the suggested solutions.

Table 15. Energy consumption as well as $\mathrm{CO}_{2}$ emission reduction of the enhanced building

\begin{tabular}{|c|c|c|}
\hline & Energy consumption $(\mathrm{kWh})$ & $\mathrm{CO}_{2}$ emission reduction $(\mathrm{kg})$ \\
\hline Typical Building & 204438.36 & - \\
\hline Enhanced building & 38814.25 & 63022.66 \\
\hline
\end{tabular}

\section{CONCLUSION}

This work techno-economically studied 13 solutions for bringing energy efficiency to a typical building in Bandar Abbas, Iran. As Bandar Abbas receives a high amount of solar insolation, utilization of solar systems for HVAC and power generation is investigated for the building. Beyond the 13 various energy solutions mentioned above, housekeeping solutions that are economically and technically feasible, are presented to reduce the energy consumption of the building. According to the results, installing shades over the southern windows, insulating the walls and the roof, using BMS, green walls, replacing the lights with LED light bulbs, installing rooftop and wall-mounted PV modules, and using a solar water heater are the economically and environmental-friendly solutions. Installing shades over the southern windows, the implementation of insulation for the walls and roof have highest energy saving, which are 40554.750, 32814.210 and $30233.260 \mathrm{kWh}$, respectively. Due to the hot and humid climate condition, laminating the windows with low-emissivity film, building a greenhouse, solar heat reservoir, and solar absorption chiller are not suggested. The 9 suggested solutions, which are convenient for this climatic condition, can reduce building energy consumption by $81 \%$ as well as preventing $63022.66 \mathrm{~kg}$ of $\mathrm{CO}_{2}$ emission. The proposed solutions could be considered as means for managing the energy and environmental crisis of hot and humid regions. 
Journal of Thermal Engineering, Research Article, Vol. 6, No. 4, pp. 633-650, July, 2020

\section{NOMENCLATURE}

$\begin{array}{ll}\text { MAE } & \text { Mean Absolute Error } \\ \text { MRE } & \text { Mean Relative Error } \\ \text { HVAC } & \text { Heating Ventilating and Air-Conditioning } \\ \text { TRNSYS } & \text { Transient System Simulation } \\ \text { CFD } & \text { Computational Fluid Dynamics } \\ \text { COP } & \text { Coefficient of Performance } \\ \text { PCM } & \text { Phase Change Material } \\ \text { ORC } & \text { Organic Rankine Cycle } \\ \text { LED } & \text { Light-Emitting Diode } \\ \text { CFL } & \text { Compact Fluorescent Lights } \\ \text { EPA } & \text { Environmental Protection Agency } \\ \text { BMS } & \text { Building Management System } \\ \text { PV } & \text { Photovoltaic } \\ \text { FPC } & \text { Flat Plate Solar Collectors } \\ \text { ETC } & \text { Evacuated Tube Solar Collectors } \\ \text { e } & \text { Theoretical } \\ \mathrm{m} & \text { Experimental } \\ \text { T } & \text { Temperature } \\ \text { G } & \text { Solar Radiation in The Collector Plane } \\ \text { a } & \text { Loss Coefficient } \\ \text { V } & \text { Voltage } \\ \text { Greek symbols } & \\ \eta & \text { Efficiency } \\ \text { Subscripts } & \\ \text { norm } & \text { Normalized } \\ i & \text { Inlet } \\ \text { a } & \text { Ambient } \\ \text { o } & \text { Optical } \\ \text { DC } & \text { Direct Current } \\ \text { s } & \text { String } \\ \mathrm{m} & \text { Module } \\ & \end{array}$

\section{REFERENCES}

[1] Lombard L., Ortiz J, Pout Ch. (2008). A review on buildings energy consumption information. Energy and Buildings 2008;40:394-398.

[2] Taner T, Sivrioglu M. Energy-exergy analysis and optimisation of a model sugar factory in Turkey. Energy 2015 93, 641-654.

[3] Taner T.. Optimisation processes of energy efficiency for a drying plant: A case of study for Turkey. Applied Thermal Engineering 2015;80:247-260.

[4] Taner T, Sivrioğlu M, Topal H, Dalkılıç AS, Wongwises S. A model of energy management analysis, case study of a sugar factory in Turkey. Sadhana 2018;43:1-20.

[5] Bellos E, Tzivanidis C. Parametric analysis and optimization of an Organic Rankine Cycle with nanofluid based solar parabolic trough collectors. Renewable Energy 2017; 114: Part B, 1376-1393.

[6] Taner T, Sivrioglu M. A techno-economic \& cost analysis of a turbine power plant: A case study for sugar plant. Renewable and Sustainable Energy Reviews 2017;78: 722-730. doi: 10.1016/j.rser.2017.04.104.

[7] Topal H, Taner T, Altınc1 Y, Amirabedin E. Application of Trigeneration with direct co-combustion of poultry waste and coal: a case study in the poultry industry from Turkey. Thermal Science, (In Press).2017 doi: 10.2298/TSCI170210137T.

[8] Topal H, and et al. Exergy analysis of a circulating fluidized bed power plant co-firing with olive pits: A case study of power plant in Turkey. Energy 2017;140:40-46. doi: 10.1016/j.energy..08.042.

[9] Zhao H, Magoulès F. A review on the prediction of building energy consumption. Renew. Sustain. Energy Rev 2012;16:3586-3592.

[10] Balaras CA, Droutsa K, Argiriou A, Asimakopoulos D.N. Potential for energy conservation in apartment buildings. Energy Build 2000;31:143-154. 
[11] Chwieduk DA. Towards modern options of energy conservation in buildings. Renew. Energy 2017;101:11941202.

[12] Aditya L, and et al. A review on insulation materials for energy conservation in buildings. Renew. Sustain. Energy Rev 2017;73:1352-1365.

[13] Liu D, Zhao FY, Tang GF. Active low-grade energy recovery potential for building energy conservation, Renew. Sustain. Energy Rev 2010;14:2736-2747.

[14] Khudhair AM, Farid MM. A review on energy conservation in building applications with thermal storage by latent heat using phase change materials. Energy Convers.Manag 2004;45:263-275.

[15] Tyagi V, Buddhi D. PCM thermal storage in buildings: A state of art, Renew. Sustain. Energy Rev 2007;11:11461166.

[16] Kenisarin M, Mahkamov K. Solar energy storage using phase change materials. Renew. Sustain. Energy Rev 2007;11:1913-1965.

[17] Sharifi NP, Shaikh AAN, Sakulich AR. Application of phase change materials in gypsum boards to meet building energy conservation goals. Energy Build 2017;138:455-467.

[18] Dabiri S, Mehrpooya M, Ghavami Nezhad, E. Latent and sensible heat analysis of PCM incorporated in a brick for cold and hot climatic conditions, utilizing computational fluid dynamics. Energy 208;159:160-171.

[19] Khan KH, Rasul MG, Khan, MMK. Energy conservation in buildings: Cogeneration and cogeneration coupled with thermal energy storage. Appl. Energy 2004;77:15-34.

[20] Anand Y, Gupta A, Tyagi SK, Anand S. Variable Capacity Absorption Cooling System Performance for Building Application. Journal of Thermal Engineering 2018;4:2303-2317.

[21] Almutairi M F, Bourisli RI. Variabele, Optimum Orientation of a Mutually-shaded Group of Building with Respect to External Solar Radiation. Journal of Thermal Engineering 2017;3:2303-2317.

[22] Hestnes AG. Building Integration of Solar Energy Systems. Sol. Energy 1999;67:181-187.

[23] Chan HY, Riffat SB, Zhu J. Review of passive solar heating and cooling technologies. Renew. Sustain. Energy Rev 2010;14:781-789.

[24] Cheng F, Wen R, Huang Z, Fang M, Liu Y, Wu X, Min X. Preparation and analysis of lightweight wall material with expanded graphite (EG)/paraffin composites for solar energy storage. Appl, Therm. Eng 2017;120:107-114.

[25] Krese G, Koželj R, Butala V, Stritih U. Thermochemical seasonal solar energy storage for heating and cooling of buildings. Energy Build 2018;164:239-253.

[26] Bellos E, Tzivanidis C, Zisopoulou E, Mitsopoulos G, Antonopoulos KA. An innovative Trombe wall as a passive heating system for a building in Athens-A comparison with the conventional Trombe wall and the insulated wall. Energy and Buildings 2016;133:754-769.

[27] Mehrpooya M, Mohammadi M, Ahmadi E. Techno-economic-environmental study of hybrid power supply system: A case study in Iran. Sustainable Energy Technologies and Assessments 2018;25:1-10.

[28] Su S, Lu H, Zhang L, Alanne K, Yu Z. Solar energy utilization patterns for different district typologies using multi-objective optimization: A comparative study in China. Sol. Energy 2017;155:246-258.

[29] Zahedi A. Solar photovoltaic (PV) energy; latest developments in the building integrated and hybrid PV systems. Renew. Energy 2006;31:711-718.

[30] Hasan A, Sarwar J, Alnoman H, Abdelbaqi S. Yearly energy performance of a photovoltaic-phase change material (PV-PCM) system in hot climate. Sol. Energy 2017;146:417-429.

[31] Baetens R, Jelle B.P, Gustavsen A. Properties, requirements and possibilities of smart windows for dynamic daylight and solar energy control in buildings: A state-of-the-art review. Sol. Energy Mater. Sol. Cells 2010;94: 87-105.

[32] Do SL, Shin M, Baltazar JC, Kim J. Energy benefits from semi-transparent BIPV window and daylight-dimming systems for IECC code-compliance residential buildings in hot and humid climates. Sol. Energy 2017;155:291303.

[33] Kuhn TE. State of the art of advanced solar control devices for buildings. Sol. Energy 2017;154:112-133.

[34] Kandilli C, Külahlı G. Performance analysis of a concentrated solar energy for lighting-power generation combined system based on spectral beam splitting. Renew. Energy 2017;101:713-727.

[35] Fraga C, Hollmuller P, Mermoud F, Lachal B. Solar assisted heat pump system for multifamily buildings: Towards a seasonal performance factor of 5? Numerical sensitivity analysis based on a monitored case study. Sol. Energy 2017;146:543-564.

[36] Poppi S, Sommerfeldt N, Bales C, Madani H, Lundqvist P. Techno-economic review of solar heat pump systems for residential heating applications. Renew. Sustain. Energy Rev 2018;81:22-32.

[37] Quoilin S, Van Den Broek M, Declaye S, Dewallef P, Lemort V. Techno-economic survey of organic Rankine cycle (ORC) systems. Renew. Sustain. Energy Rev 2013;22:168-186. 
[38] Jo J.H, Aldeman M, Lee HS, Ahn YH. Parametric analysis for cost-optimal renewable energy integration into residential buildings: Techno-economic model. Renew. Energy 2018;125:907-914.

[39] Liu G, Li M, Zhou B, Chen, Y, Liao S. General indicator for techno-economic assessment of renewable energy resources. Energy Convers. Manag 2018;156:416-426.

[40] Buonomano A, Calise F, Palombo A, Vicidomini M. Transient analysis, exergy and thermo-economic modelling of façade integrated photovoltaic/thermal solar collectors. Renew. Energy 2017; Article in Press.

[41] Lang T, Ammann D, Girod B. Profitability in absence of subsidies: A techno-economic analysis of rooftop photovoltaic self-consumption in residential and commercial buildings. Renew. Energy 2016;87:77-87.

[42] Liu G, Rasul MG, Amanullah, MTO, Khan MMK. Techno-economic simulation and optimization of residential grid-connected PV system for the Queensland climate. Renew. Energy 2012;45:146-155.

[43] Türkay BE, Telli AY. Economic analysis of standalone and grid-connected hybrid energy systems. Renew. Energy 2011;36:1931-1943.

[44] Building Design Guide for Tropical Condition, Tasman insulation New Zealand (TINZ), Fletcher Building Group.

[45] Baumann IR. The Constructional Importance of Climbing Plants. Anthos 1986;22-28.

[46] Sokhansefat T, Kasaeian AB, Rahmani K, Mohaseb S. Comparing the Performance of Flat Plate Collectors and Evacuated Tube Collectors for Buildings and Industrial Usage. The Ninth International Conference on Engineering Computational Technology, At: Napoli, Italy 2014. 